medRxiv preprint doi: https://doi.org/10.1101/2020.04.11.20062018; this version posted April 24, 2020. The copyright holder for this preprint

(which was not certified by peer review) is the author/funder, who has granted medRxiv a license to display the preprint in perpetuity.

This article is a US Government work. It is not subject to copyright under 17 USC 105 and is also made available for use under a CCO license.

\title{
Assessment of N95 respirator decontamination and re-use for SARS-CoV-2
}

2 Robert J. Fischer ${ }^{1}$, Dylan H. Morris ${ }^{2}$, Neeltje van Doremalen ${ }^{1}$, Shanda Sarchette ${ }^{1}$, M. Jeremiah Matson ${ }^{1}$

3 Trenton Bushmaker ${ }^{1}$, Claude Kwe Yinda ${ }^{1}$, Stephanie N. Seifert ${ }^{1}$, Amandine Gamble ${ }^{3}$, Brandi N.

4 Williamson ${ }^{1}$, Seth D. Judson ${ }^{4}$, Emmie de Wit ${ }^{1}$, James O. Lloyd-Smith ${ }^{3}$, Vincent J. Munster ${ }^{1}$

6 1. National Institute of Allergy and Infectious Diseases, Hamilton, MT

7 2. Princeton University, Princeton, $\mathrm{NJ}$

8 3. University of California, Los Angeles, Los Angeles, CA

9 4. University of Washington, Seattle, WA 
medRxiv preprint doi: https://doi.org/10.1101/2020.04.11.20062018; this version posted April 24, 2020. The copyright holder for this preprint (which was not certified by peer review) is the author/funder, who has granted medRxiv a license to display the preprint in perpetuity. This article is a US Government work. It is not subject to copyright under 17 USC 105 and is also made available for use under a CCO license.

Dear editor,

11 The unprecedented pandemic of COVID-19 has created worldwide shortages of personal protective

12 equipment, in particular respiratory protection such as N95 respirators(1). SARS-CoV-2 transmission is

13 frequently occurring in hospital settings, with numerous reported cases of nosocomial transmission

14 highlighting the vulnerability of healthcare workers(2). The environmental stability of SARS-CoV-2

15 underscores the need for rapid and effective decontamination methods. In general, N95 respirators are

16 designed for single use prior to disposal. Extensive literature is available for decontamination procedures

17 for N95 respirators, using either bacterial spore inactivation tests, bacteria or respiratory viruses (e.g.

18 influenza A virus)(3-6). Effective inactivation methods for these pathogens and surrogates include UV,

19 ethylene oxide, vaporized hydrogen peroxide (VHP), gamma irradiation, ozone and dry heat(3-7). The

20 filtration efficiency and N95 respirator fit has typically been less well explored, but suggest that both

21 filtration efficiency and N95 respirator fit can be affected by the decontamination method used(7, 8). For

22 a complete list of references see supplemental information.

24 Here, we analyzed four different decontamination methods - UV radiation $(260-285 \mathrm{~nm}), 70^{\circ} \mathrm{C}$ dry heat,

$2570 \%$ ethanol and vaporized hydrogen peroxide (VHP) - for their ability to reduce contamination with

26 infectious SARS-CoV-2 and their effect on N95 respirator function. For each of the decontamination

27 methods, we compared the normal inactivation rate of SARS-CoV-2 on N95 filter fabric to that on

28 stainless steel, and we used quantitative fit testing to measure the filtration performance of the N95

29 respirators after each decontamination run and 2 hours of wear, for three consecutive decontamination

30 and wear sessions (see supplemental information). VHP and ethanol yielded extremely rapid inactivation

31 both on N95 and on stainless steel (Figure 1A). UV inactivated SARS-CoV-2 rapidly from steel but more

32 slowly on N95 fabric, likely due its porous nature. Heat caused more rapid inactivation on N95 than on

33 steel; inactivation rates on N95 were comparable to UV. 
medRxiv preprint doi: https://doi.org/10.1101/2020.04.11.20062018; this version posted April 24, 2020. The copyright holder for this preprint (which was not certified by peer review) is the author/funder, who has granted medRxiv a license to display the preprint in perpetuity. This article is a US Government work. It is not subject to copyright under 17 USC 105 and is also made available for use under a CCO license.

35 Quantitative fit tests showed that the filtration performance of the N95 respirator was not markedly

36 reduced after a single decontamination for any of the four decontamination methods (Figure 1B).

37 Subsequent rounds of decontamination caused sharp drops in filtration performance of the ethanol-treated

38 masks, and to a slightly lesser degree, the heat-treated masks. The VHP and UV treated masks retained

39 comparable filtration performance to the control group after two rounds of decontamination, and

40 maintained acceptable performance after three rounds.

42 Taken together, our findings show that VHP treatment exhibits the best combination of rapid inactivation 43 of SARS-CoV-2 and preservation of N95 respirator integrity, under the experimental conditions used here 44 (Figure 1C). UV radiation kills the virus more slowly and preserves comparable respirator function. $70^{\circ} \mathrm{C}$ 45 dry heat kills with similar speed to UV and is likely to maintain acceptable fit scores for two rounds of 46 decontamination. Ethanol decontamination is not recommended due to loss of N95 integrity, echoing 47 earlier findings 5 .

All treatments, particularly UV and dry heat, should be conducted for long enough to ensure that a sufficient reduction in virus concentration has been achieved. The degree of required reduction will

51 depend upon the degree of initial virus contamination. Policymakers can use our estimated decay rates

52 together with estimates of real-world contamination to choose appropriate treatment durations (see 53 supplemental information).

55 Our results indicate that N95 respirators can be decontaminated and re-used in times of shortage for up to 56 three times for UV and HPV, and up to two times for dry heat. However, utmost care should be given to 57 ensure the proper functioning of the N95 respirator after each decontamination using readily available 58 qualitative fit testing tools and to ensure that treatments are carried out for sufficient time to achieve 59 desired risk-reduction. It will therefore be critical that FDA, CDC and OSHA guidelines with regards to

60 fit testing, seal check and respirator re-use are followed $(9,10)$. 
medRxiv preprint doi: https://doi.org/10.1101/2020.04.11.20062018; this version posted April 24, 2020. The copyright holder for this preprint (which was not certified by peer review) is the author/funder, who has granted medRxiv a license to display the preprint in perpetuity.

This article is a US Government work. It is not subject to copyright under 17 USC 105 and is also made available for use under a CCO license.
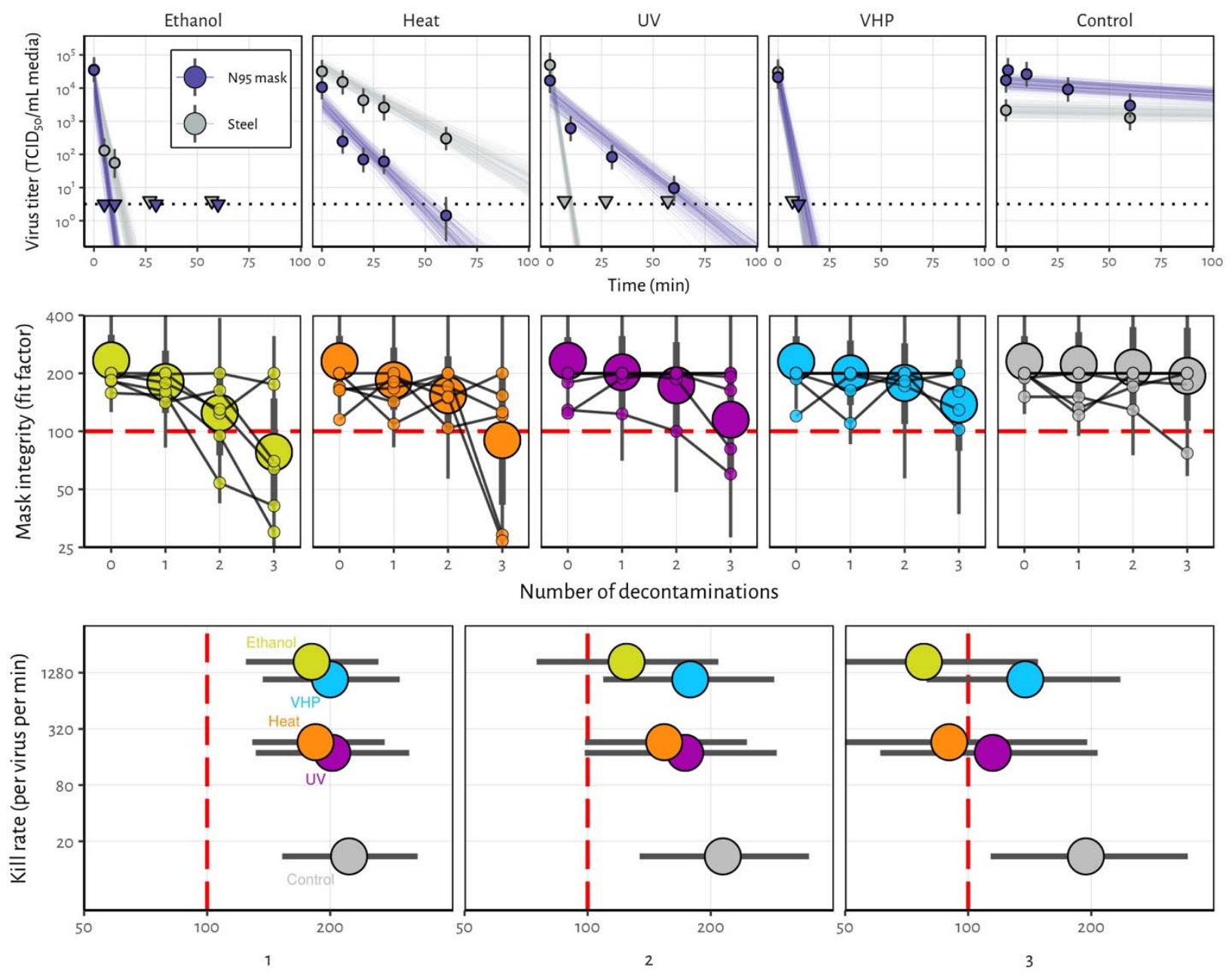

Integrity after decontamination (fit factor)

Figure 1. Decontamination of SARS-CoV-2 by four different methods. A) SARS-CoV-2 on N95 fabric and stainless steel surface was exposed to $\mathrm{UV}, 70{ }^{\circ} \mathrm{C}$ dry heat, $70 \%$ ethanol and vaporized hydrogen peroxide (VHP). $50 \mu \mathrm{l}$ of $10^{5} \mathrm{TCID}_{50} / \mathrm{mL}$ of SARS-CoV was applied on N95 and stainless steel (SS). Samples were collected at indicted time-points post exposure to the decontamination method for UV, heat and ethanol and after 10 minutes for VHP. Viable virus titer is shown in $\mathrm{TCID}_{50} / \mathrm{mL}$ media on a logarithmic scale. All samples were quantified by end-point titration on Vero E6 cells. Plots show estimated mean titer across three replicates (circles and bars show the posterior median estimate of this mean and a 95\% credible interval). Time-points with no positive wells for any replicate are plotted as triangles at the approximate single-replicate detection limit of the assay (LOD, see Appendix for

71 discussion) to indicate that a range of sub-LOD values are plausible. Steel points at the LOD are offset 
medRxiv preprint doi: https://doi.org/10.1101/2020.04.11.20062018; this version posted April 24, 2020. The copyright holder for this preprint (which was not certified by peer review) is the author/funder, who has granted medRxiv a license to display the preprint in perpetuity. This article is a US Government work. It is not subject to copyright under 17 USC 105 and is also made available for use under a CCO license.

72 slightly up and to the left to avoid overplotting. Lines show predicted decay of virus titer over time (lines;

7350 random draws per replicate from the joint posterior distribution of the exponential decay rate, i.e.

74 negative of the slope, and intercept, i.e. initial virus titer). Black dotted line shows approximate LOD:

$7510^{0.5} \mathrm{TCID}_{50} / \mathrm{mL}$ media. B) Mask integrity. Quantitative fit testing results for all the decontamination

76 methods after decontamination and 2 hours of wear, for three consecutive runs. Data from six individual

77 replicates (small dots) for each treatment are shown in addition to an estimated median fit factor (large

78 dots), an estimated 68\% range of fit factors (thick bars) and an estimated $95 \%$ range (thin bars). Fit

79 factors are a measure of filtration performance: the ratio of the concentration of particles outside the mask

80 to the concentration inside. The measurement machine reports value up to 200. A minimal fit factor of

81100 (red dashed line) is required for a mask to pass a fit test. C) SARS-CoV-2 decontamination

82 performance. Kill rate (y-axis), versus mask integrity after decontamination (x-axis; point represents

83 estimated median, bar length represents estimated $68 \%$ range). The three panels report mask integrity

84 after one, two or three decontamination cycles.

\section{References}

1. Ranney ML, Griffeth V, Jha AK. Critical Supply Shortages - The Need for Ventilators and

88 Personal Protective Equipment during the Covid-19 Pandemic. N Engl J Med. 2020 Mar 25.

$892 . \quad$ McMichael TM, Currie DW, Clark S, Pogosjans S, Kay M, Schwartz NG, et al. Epidemiology of Covid-19 in a Long-Term Care Facility in King County, Washington. N Engl J Med. 2020 Mar 27.

3. Batelle. Final Report for the Bioquell Hydrogen Peroxide Vapor (HPV) Decontamination for Reuse of N95 Respirators. 2016 [cited; Available from: https://www.fda.gov/media/136386/download

4. Fisher EM, Shaffer RE. A method to determine the available UV-C dose for the decontamination of filtering facepiece respirators. J Appl Microbiol. 2011 Jan;110(1):287-95.

95 5. Heimbuch BK, Wallace WH, Kinney K, Lumley AE, Wu CY, Woo MH, et al. A pandemic influenza preparedness study: use of energetic methods to decontaminate filtering facepiece respirators contaminated with H1N1 aerosols and droplets. Am J Infect Control. 2011 Feb;39(1):e1-9.

$98 \quad 6 . \quad$ Lin TH, Tang FC, Hung PC, Hua ZC, Lai CY. Relative survival of Bacillus subtilis spores loaded

99 on filtering facepiece respirators after five decontamination methods. Indoor Air. 2018 May 31.

1007 7. Avilash Cramer ET, Sherryl H Yu, Mitchell Galanek, Edward Lamere, Ju Li, Rajiv Gupta, Michael

101 P Short. disposable N95 masks pass qualitative fit-test but have decreases filtration efficiency after 102 cobalt-60 gamma irradiation. MedRxiv.

103 8. Lin TH, Chen CC, Huang SH, Kuo CW, Lai CY, Lin WY. Filter quality of electret masks in filtering 104 14.6-594 nm aerosol particles: Effects of five decontamination methods. PLoS One.

105 2017;12(10):e0186217.

106 9. (NIOSH) TNIfOSaH. Decontamination and Reuse of Filtering Facepiece Respirators

107.2020 [cited 2020 4/5/2020]; Available from: https://www.cdc.gov/coronavirus/2019-ncov/hcp/ppe-

108 strategy/decontamination-reuse-respirators.html 
medRxiv preprint doi: https://doi.org/10.1101/2020.04.11.20062018; this version posted April 24, 2020. The copyright holder for this preprint (which was not certified by peer review) is the author/funder, who has granted medRxiv a license to display the preprint in perpetuity.

This article is a US Government work. It is not subject to copyright under 17 USC 105 and is also made available for use under a CCO license.

109 10. CDC. Recommended Guidance for Extended Use and Limited Reuse of N95 Filtering Facepiece

110 Respirators in Healthcare Settings. 2020 [cited; Available from:

111 https://www.cdc.gov/niosh/topics/hcwcontrols/recommendedguidanceextuse.html

112

113

114

115

116

117

118

119

120

121

122

123

124

125

126

127

128

129

130

131

132

133

134

135 
medRxiv preprint doi: https://doi.org/10.1101/2020.04.11.20062018; this version posted April 24, 2020. The copyright holder for this preprint (which was not certified by peer review) is the author/funder, who has granted medRxiv a license to display the preprint in perpetuity.

This article is a US Government work. It is not subject to copyright under 17 USC 105 and is also made available for use under a CCO license.

\section{Table of contents:}

137 Supplemental methods

138 Supplemental table

139 Code and data availability

140 Acknowledgements

141 Supplemental references page 1

page 2

page 10

page 10

page 11

page 11 
medRxiv preprint doi: https://doi.org/10.1101/2020.04.11.20062018; this version posted April 24, 2020. The copyright holder for this preprint (which was not certified by peer review) is the author/funder, who has granted medRxiv a license to display the preprint in perpetuity.

This article is a US Government work. It is not subject to copyright under 17 USC 105 and is also made available for use under a CCO license.

\section{Supplemental methods}

\section{Short literature review on mask decontamination}

The COVID-19 pandemic has highlighted the necessity for large-scale decontamination procedures

145 for personal protective equipment (PPE), in particular N95 respirator masks(1). SARS-CoV-2 has

146 frequently been detected on PPE of healthcare workers(11). The environmental stability of SARS-CoV-2

147 underscores the need for rapid and effective decontamination methods(12). Extensive literature is

148 available for decontamination procedures for N95 respirators, using either bacterial spore inactivation

149 tests, bacteria or respiratory viruses (e.g. influenza A virus)(3-6, 9, 13-15). Effective inactivation methods

150 for these pathogens and surrogates include UV, ethylene oxide, vaporized hydrogen peroxide (VHP),

151 gamma irradiation, ozone and dry heat $(4,5,7,9,14-16)$. The filtration efficiency and N95 respirator fit

152 has typically been less well explored, but suggest that both filtration efficiency and N95 respirator fit can

153 be affected by the decontamination method used(7, 8). It will therefore be critical that FDA, CDC and

154 OSHA guidelines with regards to fit testing, seal check and respirator re-use are followed(9, 17-20).

\section{Laboratory experiments}

156 Viruses and titration

HCoV-19 nCoV-WA1-2020 (MN985325.1) was the SARS-CoV-2 strain used in our

158 comparison(21). Virus was quantified by end-point titration on Vero E6 cells as described previously(22).

159 Virus titrations were performed by end-point titration in Vero E6 cells. Cells were inoculated with 10-fold

160 serial dilutions in four-fold of samples taken from N95 mask and stainless steel surfaces (see below). One

161 hour after inoculation of cells, the inoculum was removed and replaced with $100 \mu 1$ (virus titration)

162 DMEM (Sigma-Aldrich) supplemented with $2 \%$ fetal bovine serum, $1 \mathrm{mM}$ L-glutamine, $50 \mathrm{U} / \mathrm{ml}$

163 penicillin and $50 \mu \mathrm{g} / \mathrm{ml}$ streptomycin. Six days after inoculation, cytopathogenic effect was scored and

164 the $\mathrm{TCID}_{50}$ was calculated (see below). Wells presenting cytopathogenic effects due to media toxicity 
medRxiv preprint doi: https://doi.org/10.1101/2020.04.11.20062018; this version posted April 24, 2020. The copyright holder for this preprint (which was not certified by peer review) is the author/funder, who has granted medRxiv a license to display the preprint in perpetuity. This article is a US Government work. It is not subject to copyright under 17 USC 105 and is also made available for use under a CCO license.

165 (e.g., due to the presence of ethanol or hydrogen peroxide) rather than viral infection were removed from 166 the titer inference procedure.

$167 \quad$ N95 and stainless steel surface

168 N95 material discs were made by punching 9/16" (15 mm) fabric discs from N95 respirators, 169 AOSafety N9504C respirators (Aearo Company Southbridge, MA). The stainless steel 304 alloy discs 170 were purchased from Metal Remnants (https://metalremnants.com/) as described previously. $50 \mu \mathrm{L}$ of 171 SARS-CoV-2 was spotted onto each disc. A 0 time-point measurement was taken prior to exposing the 172 discs to the disinfection treatment. At each sampling time-point, discs were rinsed 5 times by passing the 173 medium over the stainless steel or through the N95 disc. The medium was transferred to a vial and frozen 174 at $-80^{\circ} \mathrm{C}$ until titration. All experimental conditions were performed in triplicate.

175 Decontamination methods

176 Ultraviolet light. Plates with fabric and steel discs were placed under an LED high power UV germicidal 177 lamp (effective UV wavelength 260-285nm) without the titanium mesh plate (LEDi2, Houston, Tx) 50 $178 \mathrm{~cm}$ from the UV source. At $50 \mathrm{~cm}$ the UVC power was measured by the manufacturer at $550 \mu \mathrm{W} / \mathrm{cm}^{2}$.

179 Plates were removed at 10, 30 and 60 minutes and $1 \mathrm{~mL}$ of cell culture medium added. The energy the 180 discs were exposed to at 10,30 and $60 \mathrm{~min}$ is $0.33 \mathrm{~J} / \mathrm{cm}^{2}, 0.99 \mathrm{~J} / \mathrm{cm}^{2}$, and $1.98 \mathrm{~J} / \mathrm{cm}^{2}$ respectively. While 181 the CDC has no specific recommendations on the minimum dose, they do report that a $1 \mathrm{~J} / \mathrm{cm} 2 \mathrm{dose}$ can 182 reduce tested viable viral loads by $99.9 \%{ }^{4}$.

183 Heat treatment. Plates with fabric and steel discs were placed in a $70^{\circ} \mathrm{C}$ oven. Plates were removed at 10 , 18420,30 and 60 minutes and $1 \mathrm{~mL}$ of cell culture medium added.

$18570 \%$ ethanol. Fabric and steel discs were placed into the wells of one 24 well plate per time-point and 186 sprayed with $70 \%$ ethanol to saturation. The plate was tipped to near vertical and 5 passes of ethanol were 
medRxiv preprint doi: https://doi.org/10.1101/2020.04.11.20062018; this version posted April 24, 2020. The copyright holder for this preprint (which was not certified by peer review) is the author/funder, who has granted medRxiv a license to display the preprint in perpetuity. This article is a US Government work. It is not subject to copyright under 17 USC 105 and is also made available for use under a CCO license.

187 sprayed onto the discs from approximately $10 \mathrm{~cm}$. After 10 minutes, $1 \mathrm{~mL}$ of cell culture medium was 188 added.

189 VHP. Plates with fabric and steel discs were placed into a Panasonic MCO-19AIC-PT (PHC Corp. of 190 North America Wood Dale, IL) incubator with VHP generation capabilities and exposed to hydrogen 191 peroxide (approximately $1000 \mathrm{ppm}$ ). The exposure to VHP was 7 minutes, after the inactivation of the 192 hydrogen peroxide, the plate was removed and $1 \mathrm{~mL}$ of cell culture medium was added.

193 Control. Plates with fabric and steel discs and steel plates were maintained at $21-23^{\circ} \mathrm{C}$ and $40 \%$ relative 194 humidity for up to four days. After the designated time-points, $1 \mathrm{~mL}$ of cell culture medium was added.

N95 mask integrity testing

N95 Mask (3M ${ }^{\mathrm{TM}}$ Aura $^{\mathrm{TM}}$ Particulate Respirator 9211+/37193) integrity testing after 2 hours of wear 197 and decontamination, for three consecutive rounds, was performed for a total of 6 times for each 198 decontamination condition and control condition. Masks were worn by subjects and integrity was 199 quantitatively determined using the Portacount Respirator fit tester (TSI, 8038) with the N95 companion 200 component, following the modified ambient aerosol condensation nuclei counter quantitative fit test 201 protocol approved by the OSHA ${ }^{18}$. Subjects were asked to bend over for 40 seconds, talk for 50 seconds, 202 move head from side-to-side for 50 seconds, and move head up-and-down for 50 seconds whilst aerosols 203 on inside and outside of mask were measured. By convention, this fit test is passed when the final score is $204 \geq 100$. For the N95 integrity testing, a Honeywell Mistmate humidifier (cat\#HUL520B) was used for 205 particle generation.

Statistical analyses

In the model notation that follows, the symbol $\sim$ denotes that a random variable is distributed 208 according to the given distribution. Normal distributions are parametrized as Normal(mean, standard 209 deviation). Positive-constrained normal distributions ("Half-Normal") are parametrized as Half- 
medRxiv preprint doi: https://doi.org/10.1101/2020.04.11.20062018; this version posted April 24, 2020. The copyright holder for this preprint (which was not certified by peer review) is the author/funder, who has granted medRxiv a license to display the preprint in perpetuity.

This article is a US Government work. It is not subject to copyright under 17 USC 105 and is also made available for use under a CCO license.

210 Normal(mode, standard deviation). Normal distributions truncated to the interval $[0,1]$ are parameterized

211 as TruncNormal(mode, standard deviation).

212 We use <Distribution Name $>\operatorname{CDF}(\mathrm{x} \mid$ parameters) and <Distribution Name $>$ CCDF to denote the

213 cumulative distribution function and complementary cumulative distribution functions of a probability

214 distribution, respectively. So for example $\operatorname{NormalCDF}(5 \mid 0,1)$ is the value of the $\operatorname{Normal}(0,1)$

215 cumulative distribution function at 5.

216 We use logit $(x)$ and $\operatorname{invlogit}(x)$ to denote the logit and inverse logit functions, respectively:

$$
\operatorname{logit}(x)=\ln \frac{x}{1-x}
$$

$$
\operatorname{invlogit}(x)=\frac{\mathrm{e}^{x}}{1+\mathrm{e}^{x}}
$$

\section{Mean titer inference}

220 We inferred mean titers across sets of replicates using a Bayesian model. The $\log _{10}$ titers $v_{i j k}$ (the titer

221 for the sample from replicate $k$ of time-point $j$ of experiment $i$ ) were assumed to be normally distributed 222 about a mean $\mu_{i j}$ with a standard deviation $\sigma$. We placed a very weakly informative normal prior on the $223 \log _{10}$ mean titers $\mu_{i j}$ :

$$
\mu_{i j} \sim \operatorname{Normal}(3,3)
$$

225 We placed a weakly informative normal prior on the standard deviation:

$$
\sigma \sim \operatorname{Normal}(0,0.5)
$$

We then modeled individual positive and negative wells for sample $i j k$ according to a Poisson single-

228 hit model(23). That is, the number of virions that successfully infect cells in a given well is Poisson 229 distributed with mean: 
medRxiv preprint doi: https://doi.org/10.1101/2020.04.11.20062018; this version posted April 24, 2020. The copyright holder for this preprint (which was not certified by peer review) is the author/funder, who has granted medRxiv a license to display the preprint in perpetuity. This article is a US Government work. It is not subject to copyright under 17 USC 105 and is also made available for use under a CCO license.

231 where $v$ is the $\log _{10}$ virus titer in $\mathrm{TCID}_{50}$, where $v$ is the $\log _{10}$ virus titer in $\mathrm{TCID}_{50}$, and the well is infected

232 if at least one virion successfully infects a cell. The value of the mean derives from the fact that our units

233 are $\mathrm{TCID}_{50}$; the probability of infection at $v=0$, i.e. $1 \mathrm{TCID}_{50}$, is equal to $1-\mathrm{e}^{-\ln (2) \times 1}=0.5$.

234 Let $Y_{i j k d l}$ be a binary variable indicating whether the $l^{\text {th }}$ well of dilution factor $d$ (expressed as $\log _{10}$ 235 dilution factor) of sample $i j k$ was positive (so $Y_{i j k d l}=1$ if the well was positive and 0 otherwise), which 236 will occur as long as at least one virion successfully infects a cell.

$238 \log _{10}$ titer $v_{i j k}$ is given by:

$$
\mathrm{L}\left(Y_{i j k d l}=1 \mid v_{i j k}\right)=1-e^{-\ln (2) \times 10^{x}}
$$

240 Where

$$
x=v_{i j k}-d
$$

242 is the expected concentration, measured in $\log _{10} \mathrm{TCID} 50$, in the dilute sample. This is simply the

243 probability that a Poisson random variable with mean $\left(-\ln (2) \times 10^{x}\right)$ is greater than 0 . Similarly, the

244 conditional probability of observing $Y_{i j k d l}=0$ given a true underlying titer $\log _{10}$ titer $v_{i j k}$ is given by:

$$
\mathrm{L}\left(Y_{i j k d l}=0 \mid v_{i j k}\right)=e^{-\ln (2) \times 10^{x}}
$$

246 which is the probability that the Poisson random variable is 0.

247 This gives us our likelihood function, assuming independence of outcomes across wells. 
medRxiv preprint doi: https://doi.org/10.1101/2020.04.11.20062018; this version posted April 24, 2020. The copyright holder for this preprint (which was not certified by peer review) is the author/funder, who has granted medRxiv a license to display the preprint in perpetuity. This article is a US Government work. It is not subject to copyright under 17 USC 105 and is also made available for use under a CCO license.

250 sampling method, as expected. We therefore estimated the decay rates of viable virus titers using a

251 Bayesian regression analogous to that used in van Doremalen et al., 2020(12). This modeling approach

252 allowed us to account for differences in initial inoculum levels across replicates as well as other sources

253 of experimental noise. The model yields estimates of posterior distributions of viral decay rates and half-

254 lives in the various experimental conditions - that is, estimates of the range of plausible values for these 255 parameters given our data, with an estimate of the overall uncertainty(24).

Our data consist of 10 experimental conditions: 2 materials (N95 masks and stainless steel) by 5 257 treatments (no treatment, ethanol, heat, UV and VHP). Each has three replicates, and multiple time-points 258 for each replicate. We analyze the two materials separately. For each, we denote by $Y_{i j k d l}$ the positive or 259 negative status (see above) for well $l$ which has dilution $d$ for the titer $v_{i j k}$ from experimental condition $i$ 260 during replicate $j$ at time-point $k$.

261 We model each replicate $j$ for experimental condition $i$ as starting with some true initial $\log _{10}$ titer $262 v_{i j}(0)=v_{i j 0}$. We assume that viruses in experimental condition $i$ decay exponentially at a rate $\lambda_{i}$ over time $t$. 263 It follows that:

$$
v_{i j}(t)=v_{i j 0}-\lambda_{i} t
$$

We use the direct-from-well data likelihood function described above, except that now instead of 266 estimating titer distribution about a shared mean $\mu_{i j}$ we estimate $\lambda_{i}$ under the assumptions that our 267 observed well data $Y_{i j k d l}$ reflect the titers $v_{i j}(t)$.

We place a weakly informative Normal prior distribution on the initial $\log _{10}$ titers $v_{i j 0}$ to rule out implausibly large or small values (e.g. in this case undetectable $\log _{10}$ titers or $\log _{10}$ titers much higher than 
medRxiv preprint doi: https://doi.org/10.1101/2020.04.11.20062018; this version posted April 24, 2020. The copyright holder for this preprint

(which was not certified by peer review) is the author/funder, who has granted medRxiv a license to display the preprint in perpetuity.

This article is a US Government work. It is not subject to copyright under 17 USC 105 and is also made available for use under a CCO license.

$$
v_{i j 0} \sim \operatorname{Normal}(4.5,2)
$$

273 We placed a weakly informative Half-Normal prior on the exponential decay rates $\lambda_{i}$ :

$$
\lambda_{i} \sim \operatorname{Half-Normal}(0.5,4)
$$

276 units of $\log _{10} \mathrm{TCID}_{50} / \mathrm{mL}$.

\section{Mask integrity estimation}

278 To quantify the decay of mask integrity after repeated decontamination, we used a logit-linear spline

279 Bayesian regression to estimate the rate of degradation of mask fit factors over time, accounting for the

280 fact that fit factors are interval-censored ratios. Fit factors are defined as the ratio of exterior

281 concentration to interior concentration of a test aerosol. They are reported to the nearest integer, up to a 282 maximum readout of 200 , but arbitrarily large true fit factors are possible as the mask performance 283 approaches perfect filtration.

We had 6 replicate masks $j$ for each of 5 treatments $i$ (no decontamination, ethanol, heat, UV and

285 VHP). Each mask $j$ was assessed for fit factor at 4 time-points $k$ : before decontamination, and then after 1 ,

2862 , and 3 decontamination cycles. We label the control treatment $i=0$. So we denote by $F_{i j k}$ the fit factor

287 for the $j^{\text {th }}$ mask from the $i^{\text {th }}$ treatment after $k$ decontaminations (with $k=0$ for the initial value).

We first converted fit factors $F_{i j k}$ to the equivalent observed filtration rate $Y_{i j k}$ by:

$$
Y=1-1 / F
$$


medRxiv preprint doi: https://doi.org/10.1101/2020.04.11.20062018; this version posted April 24, 2020. The copyright holder for this preprint

(which was not certified by peer review) is the author/funder, who has granted medRxiv a license to display the preprint in perpetuity.

This article is a US Government work. It is not subject to copyright under 17 USC 105 and is also made available for use under a CCO license.

291 We modeled the censored observation process as follows. $\operatorname{logit}\left(Y_{i j k}\right)$ values are observed with

292 Gaussian error about the true filtration $\operatorname{logit}\left(p_{i j k}\right)$, with an unknown standard deviation $\sigma_{o}$, and then

293 converted to fit factors, which are then censored:

$$
\operatorname{logit}\left(Y_{i j k}\right) \sim \operatorname{Normal}\left(\operatorname{logit}\left(p_{i j k}\right), \sigma_{o}\right)
$$

$296 F_{i j k} \geq 200$ we have a conditional probability of observing the data given the parameters of

$$
\mathrm{L}\left(F_{\mathrm{ijk}} \mid p_{i j k}, \sigma_{o}\right)=\operatorname{NormalCCDF}\left(\operatorname{logit}(1-1 / 200) \mid \operatorname{logit}\left(p_{i j k}\right) \sigma_{o}\right)
$$

298 That is, we calculate the probability of observing a value of $F$ greater than or equal to 200 (equivalent a 299 value of $Y$ greater than or equal to $1-1 / 200$ ), given our parameters.

For $1.5 \leq F_{i j k}<200$, we first calculate the upper and lower bounds of our observation $Y^{+}{ }_{i j k}=1-1 /$

$301\left(F_{\mathrm{ijk}}-0.5\right)$ and $Y_{i j k}=1-1 /\left(F_{i j k}-0.5\right)$. Then:

$$
\mathrm{L}\left(F_{\mathrm{ijk}} \mid p_{i j k}, \sigma_{o}\right)=\operatorname{NormalCDF}\left(\operatorname{logit}\left(Y_{i j k}^{+}\right) \mid \operatorname{logit}\left(p_{i j k}\right) \sigma_{o}\right)-
$$

$$
\operatorname{NormalCDF}\left(\operatorname{logit}\left(Y_{i j k}^{-}\right) \mid \operatorname{logit}\left(p_{i j k}\right) \sigma_{o}\right)
$$

304 That is, we calculate the probability of observing a value between $Y_{i j k}^{+}$and $Y_{i j k}$, given our parameters. 
medRxiv preprint doi: https://doi.org/10.1101/2020.04.11.20062018; this version posted April 24, 2020. The copyright holder for this preprint

(which was not certified by peer review) is the author/funder, who has granted medRxiv a license to display the preprint in perpetuity.

This article is a US Government work. It is not subject to copyright under 17 USC 105 and is also made available for use under a CCO license.

\section{Decay model}

We assumed that each mask had some true initial filtration rate $p_{i j 0}$. We assumed that these were

307 logit-normally distributed about some unknown mean mask initial filtration rate $p_{\text {avg }}$ with a standard

308 deviation $\sigma_{p}$, that is:

$$
\operatorname{logit}\left(p_{i j 0}\right) \sim \operatorname{Normal}\left(\operatorname{logit}\left(p_{\text {avg }}\right), \sigma_{p}\right)
$$

We then assumed that the logit of the filtration rate, logit $\left(p_{i j k}\right)$, decreased after each decontamination

311 by a quantity $d_{0 k}+d_{i k}$, where $d_{0 k}$ is natural degradation during the $k^{\text {th }}$ trial in the absence of

312 decontamination (i.e. the degradation rate in the control treatment, $i=0$ ), and $d_{i k}$ is the additional

313 degrading effect of the $k^{\text {th }}$ decontamination treatment of type $i>0$ ). So for $k=1,2,3$ and $i>0$ :

$$
\operatorname{logit}\left(p_{i j k}\right)=\operatorname{logit}\left(p_{i j(k-1)}\right)-\left(d_{0 k}+d_{i k}\right)+\varepsilon_{i j k}
$$

315 where $\varepsilon_{i j k}$ is a normally-distributed error term with an inferred standard deviation $\sigma_{\varepsilon i k}$ for each treatment

316 and decontamination level.

$$
\varepsilon_{i j k} \sim \operatorname{Normal}\left(0, \sigma_{\varepsilon i k}\right)
$$

318 And for the control $i=0$ :

$$
\operatorname{logit}\left(p_{0 j k}\right)=\operatorname{logit}\left(p_{0 j(k-1)}\right)-d_{0 k}+\varepsilon_{0 j k}
$$

We placed a weakly informative Half-Normal prior on the control degradation rate $d_{0}$ :

$$
d_{0} \sim \operatorname{Half-Normal}(0,0.5)
$$

323 We placed a weakly informative Half-Normal prior on the non-control degradation rates $d_{i}, i>0$ : 
medRxiv preprint doi: https://doi.org/10.1101/2020.04.11.20062018; this version posted April 24, 2020. The copyright holder for this preprint

(which was not certified by peer review) is the author/funder, who has granted medRxiv a license to display the preprint in perpetuity.

This article is a US Government work. It is not subject to copyright under 17 USC 105 and is also made available for use under a CCO license.

$$
d_{i} \sim \text { Half-Normal }(0.25,0.5)
$$

325 reflecting the conservative assumption that decontamination should degrade the mask at least somewhat.

We placed a Truncated Normal prior on the mean initial filtration $p_{\text {avg: }}$ :

$$
p_{\text {avg }} \sim \text { TruncNormal }(0.995,0.02)
$$

328 The mode of 0.995 corresponds to the maximum measurable fit factor of 200 . The standard deviation of 3290.02 leaves it plausible that some masks could start near or below the minimum acceptable threshold fit 330 factor of 100, which corresponds to a $p$ of 0.99 .

331 We placed weakly informative Half-Normal priors on the logit-space standard deviations $\sigma_{p}, \sigma_{\varepsilon i k}$, and

$332 \sigma_{o} . \sigma_{p}$ reflects variation in individual masks' initial filtration about $p_{\text {avg }}$. The various $\sigma_{\varepsilon i k}$ reflect variation in 333 masks' true degree of degradation between decontaminations about the expected degree of decay, and $\sigma_{o}$ 334 reflects noise in the observation process.

$$
\sigma_{p}, \sigma_{o} \sim \operatorname{Half-Normal}(0,0.5)
$$

\section{Markov Chain Monte Carlo Methods}


medRxiv preprint doi: https://doi.org/10.1101/2020.04.11.20062018; this version posted April 24, 2020. The copyright holder for this preprint (which was not certified by peer review) is the author/funder, who has granted medRxiv a license to display the preprint in perpetuity. This article is a US Government work. It is not subject to copyright under 17 USC 105 and is also made available for use under a CCO license.

For all Bayesian models, we drew posterior samples using Stan (Stan Core Team 2018), which

344 implements a No-U-Turn Sampler (a form of Markov Chain Monte Carlo), via its R interface RStan. We

345 ran four replicate chains from random initial conditions for 2000 iterations, with the first 1000 iterations

346 as a warmup/adaptation period. We saved the final 1000 iterations from each chain, giving us a total of

3474000 posterior samples. We assessed convergence by inspecting trace plots and examining $R \square$ and

348 effective sample size $\left(n_{\text {eff }}\right)$ statistics.

$\underline{\text { Limit of detection (LOD) }}$

End-point titration has an approximate limit of detection set by the volume of the undilute sample

351 deposited in each well. If all wells - including those containing undiluted sample - are negative and a

352 Poisson single-hit model is used, the best guess is that the true titer lies somewhere below $1 \mathrm{TCID}_{50} /$

353 (volume of deposited sample). How far below is determined by the number of wells. For four wells, as

354 was standard in our experiments, the first quarter $\log _{10}$ titer at which 0 wells is the most likely outcome is

$35510^{-0.5} \mathrm{TCID}_{50}$ per volume of sample. This is also the imputed Speaman-Karber titer in that case. Since we

356 used samples of volume $0.1 \mathrm{~mL}$, this corresponds to a value of $10^{0.5} \mathrm{TCID}_{50} / \mathrm{mL}$. So although we do not

357 use the Spearman-Karber method here (since we infer mean titers directly from the well data) we use that

358 LOD value to plot samples for which no replicate had a positive well (since the posterior distribution in

359 that case covers a wide-range of sub-threshold values).

\section{Supplemental table}

361 Table S1. Effect of decontamination method on SARS-CoV-2 viability. Results are reported as the

362 median and upper- and lower-limits of the $95 \%$ credible interval of the estimated half-life, and time

363 needed to reduce viable SARS-CoV-2 load by a factor of one thousand or one million, based on the

364 posterior distribution of the exponential decay rate of the virus on different materials following different

365 decontamination treatments. 


\begin{tabular}{|c|c|c|c|c|c|c|c|c|c|c|}
\hline \multirow[b]{2}{*}{ Treatme } & \multirow[b]{2}{*}{$\begin{array}{l}\text { Materia } \\
\text { l }\end{array}$} & \multicolumn{3}{|c|}{ Half-life (min) } & \multicolumn{3}{|c|}{$\begin{array}{l}\text { Time to one thousandth } \\
\text { (min) }\end{array}$} & \multicolumn{3}{|c|}{ Time to one millionth (min) } \\
\hline & & Median & $2.5 \%$ & $97.5 \%$ & Median & $2.5 \%$ & $97.5 \%$ & Median & $2.5 \%$ & 97.5\% \\
\hline & $\begin{array}{l}\mathrm{N} 95 \\
\text { mask }\end{array}$ & 78.7 & 66.1 & 90.4 & 784 & 659 & 901 & $\begin{array}{r}1.57 \times \\
10^{3}\end{array}$ & $\begin{array}{r}1.32 \times \\
10^{3}\end{array}$ & $1.8 \times 10$ \\
\hline & Steel & 290 & 244 & 327 & $\begin{array}{r}2.89 \times \\
10^{3}\end{array}$ & $\begin{array}{r}2.43 \times \\
10^{3}\end{array}$ & $\begin{array}{r}3.26 \times \\
10^{3}\end{array}$ & $\begin{array}{r}5.77 \times \\
10^{3}\end{array}$ & $\begin{array}{r}4.86 \times \\
10^{3}\end{array}$ & $\begin{array}{r}6.53 ; \\
10\end{array}$ \\
\hline Ethanol & $\begin{array}{l}\mathrm{N} 95 \\
\text { mask }\end{array}$ & 0.647 & 0.557 & 0.733 & 6.45 & 5.55 & 7.31 & 12.9 & 11.1 & 14.1 \\
\hline & Steel & 1.08 & 0.895 & 1.26 & 10.8 & 8.92 & 12.5 & 21.6 & 17.8 & 2 \\
\hline Heat & $\begin{array}{l}\mathrm{N} 95 \\
\text { mask }\end{array}$ & 4.7 & 3.93 & 5.48 & 46.9 & 39.2 & 54.6 & 93.7 & 78.4 & 10 \\
\hline & Steel & 8.85 & 7.42 & 10.2 & 88.1 & 74 & 101 & 176 & 148 & 20 \\
\hline UV & $\begin{array}{l}\mathrm{N} 95 \\
\text { mask }\end{array}$ & 6.12 & 5.27 & 6.87 & 61 & 52.6 & 68.5 & 122 & 105 & $13^{\circ}$ \\
\hline & Steel & 0.736 & 0.651 & 0.805 & 7.33 & 6.48 & 8.02 & 14.7 & 13 & 11 \\
\hline VHP & $\begin{array}{l}\mathrm{N} 95 \\
\text { mask }\end{array}$ & 0.999 & 0.83 & 1.14 & 9.95 & 8.27 & 11.3 & 19.9 & 16.5 & $22 .^{\prime}$ \\
\hline
\end{tabular}


medRxiv preprint doi: https://doi.org/10.1101/2020.04.11.20062018; this version posted April 24, 2020. The copyright holder for this preprint (which was not certified by peer review) is the author/funder, who has granted medRxiv a license to display the preprint in perpetuity.

This article is a US Government work. It is not subject to copyright under 17 USC 105 and is also made available for use under a CCO license.

Steel

0.77

0.673

0.846

7.67

6.71

8.43

15.3

13.4

\section{Code and data availability}

369 Code and data to reproduce the Bayesian estimation results and produce corresponding figures are

370 archived online at OSF: https://doi.org/10.17605/OSF.IO/mkg9b and available on Github:

371 https://github.com/dylanhmorris/n95-decontamination 
medRxiv preprint doi: https://doi.org/10.1101/2020.04.11.20062018; this version posted April 24, 2020. The copyright holder for this preprint (which was not certified by peer review) is the author/funder, who has granted medRxiv a license to display the preprint in perpetuity. This article is a US Government work. It is not subject to copyright under 17 USC 105 and is also made available for use under a CCO license.

\section{Acknowledgements}

We would like to thank Madison Hebner, Julia Port, Kimberly Meade-White, Irene Offei Owusu,

374 Victoria Avanzato and Lizzette Perez-Perez for excellent technical assistance. This research was

375 supported by the Intramural Research Program of the National Institute of Allergy and Infectious

376 Diseases (NIAID), National Institutes of Health (NIH). JOL-S and AG were supported by the Defense

377 Advanced Research Projects Agency DARPA PREEMPT \# D18AC00031 and the UCLA AIDS Institute

378 and Charity Treks, and JOL-S was supported by the U.S. National Science Foundation (DEB-1557022),

379 the Strategic Environmental Research and Development Program (SERDP, RC $\square$ 2635) of the U.S.

380 Department of Defense. Names of specific vendors, manufacturers, or products are included for public

381 health and informational purposes; inclusion does not imply endorsement of the vendors, manufacturers,

382 or products by the US Department of Health and Human Services.

\section{Supplemental references}

384 1. Ranney ML, Griffeth V, Jha AK. Critical Supply Shortages - The Need for Ventilators and

385 Personal Protective Equipment during the Covid-19 Pandemic. N Engl J Med. 2020 Mar 25.

$3862 . \quad$ McMichael TM, Currie DW, Clark S, Pogosjans S, Kay M, Schwartz NG, et al. Epidemiology of

387 Covid-19 in a Long-Term Care Facility in King County, Washington. N Engl J Med. 2020 Mar 27.

388 3. Batelle. Final Report for the Bioquell Hydrogen Peroxide Vapor (HPV) Decontamination for Reuse

389 of N95 Respirators. 2016 [cited; Available from: https://www.fda.gov/media/136386/download

390 4. Fisher EM, Shaffer RE. A method to determine the available UV-C dose for the decontamination

391 of filtering facepiece respirators. J Appl Microbiol. 2011 Jan;110(1):287-95.

392 5. Heimbuch BK, Wallace WH, Kinney K, Lumley AE, Wu CY, Woo MH, et al. A pandemic influenza

393 preparedness study: use of energetic methods to decontaminate filtering facepiece respirators

394 contaminated with H1N1 aerosols and droplets. Am J Infect Control. 2011 Feb;39(1):e1-9.

395 6. Lin TH, Tang FC, Hung PC, Hua ZC, Lai CY. Relative survival of Bacillus subtilis spores loaded

396 on filtering facepiece respirators after five decontamination methods. Indoor Air. 2018 May 31. 
medRxiv preprint doi: https://doi.org/10.1101/2020.04.11.20062018; this version posted April 24, 2020. The copyright holder for this preprint (which was not certified by peer review) is the author/funder, who has granted medRxiv a license to display the preprint in perpetuity. This article is a US Government work. It is not subject to copyright under 17 USC 105 and is also made available for use under a CCO license.

397 7. Avilash Cramer ET, Sherryl H Yu, Mitchell Galanek, Edward Lamere, Ju Li, Rajiv Gupta, Michael

398 P Short. disposable N95 masks pass qualitative fit-test but have decreases filtration efficiency after

399 cobalt-60 gamma irradiation. MedRxiv.

400 8. Lin TH, Chen CC, Huang SH, Kuo CW, Lai CY, Lin WY. Filter quality of electret masks in filtering 401 14.6-594 nm aerosol particles: Effects of five decontamination methods. PLoS One.

$402 \quad 2017 ; 12(10): e 0186217$.

403 9. (NIOSH) TNIfOSaH. Decontamination and Reuse of Filtering Facepiece Respirators

404 . 2020 [cited 2020 4/5/2020]; Available from: https://www.cdc.gov/coronavirus/2019-ncov/hcp/ppe-

405 strategy/decontamination-reuse-respirators.html

406 10. CDC. Recommended Guidance for Extended Use and Limited Reuse of N95 Filtering Facepiece

407 Respirators in Healthcare Settings. 2020 [cited; Available from:

408 https://www.cdc.gov/niosh/topics/hcwcontrols/recommendedguidanceextuse.html

409 11. Ong SWX, Tan YK, Chia PY, Lee TH, Ng OT, Wong MSY, et al. Air, Surface Environmental, and

410 Personal Protective Equipment Contamination by Severe Acute Respiratory Syndrome Coronavirus 2

411 (SARS-CoV-2) From a Symptomatic Patient. JAMA. 2020 Mar 4.

412 12. van Doremalen N, Bushmaker T, Morris DH, Holbrook MG, Gamble A, Williamson BN, et al.

413 Aerosol and Surface Stability of SARS-CoV-2 as Compared with SARS-CoV-1. N Engl J Med. 2020 Mar

41417.

415 13. Heimbuch BK, Kinney K, Lumley AE, Harnish DA, Bergman M, Wander JD. Cleaning of filtering

416 facepiece respirators contaminated with mucin and Staphylococcus aureus. Am J Infect Control. 2014

417 Mar;42(3):265-70.

418 14. Mills D, Harnish DA, Lawrence C, Sandoval-Powers M, Heimbuch BK. Ultraviolet germicidal

419 irradiation of influenza-contaminated N95 filtering facepiece respirators. Am J Infect Control. 2018

420 Jul;46(7):e49-e55.

$421 \quad$ 15. Viscusi DJ, Bergman MS, Eimer BC, Shaffer RE. Evaluation of five decontamination methods for 422 filtering facepiece respirators. Ann Occup Hyg. 2009 Nov;53(8):815-27. 
medRxiv preprint doi: https://doi.org/10.1101/2020.04.11.20062018; this version posted April 24, 2020. The copyright holder for this preprint

(which was not certified by peer review) is the author/funder, who has granted medRxiv a license to display the preprint in perpetuity.

This article is a US Government work. It is not subject to copyright under 17 USC 105 and is also made available for use under a CCO license.

423 16. CDC. Chemical Disinfectants, Guideline for Disinfection and Sterilization in Healthcare Facilities.

4242008 [cited; Available from: https://www.cdc.gov/infectioncontrol/quidelines/disinfection/disinfection-

425 methods/chemical.html\#Hydrogen

426 17. FDA. N95 Respirators and Surgical Masks (Face Masks). 2020 [cited 2020 4/5/2020]; Available

427 from: https://www.fda.gov/medical-devices/personal-protective-equipment-infection-control/n95-

428 respirators-and-surgical-masks-face-masks

429 18. Administration OSaH. Temporary Enforcement Guidance - Healthcare Respiratory Protection

430 Annual Fit-Testing for N95 Filtering Facepieces During the COVID-19 Outbreak. 2020 [cited; Available

431 from: https://www.osha.gov/memos/2020-03-14/temporary-enforcement-guidance-healthcare-respiratory-

432 protection-annual-fit

433 19. Administration OSaH. User Seal Check Procedures (Mandatory). 2020 [cited 2020 April 11];

434 Available from: https://www.osha.gov/laws-regs/regulations/standardnumber/1910/1910.134AppB1

435 20. Administration OSaH. Respirator Fit Testing [WWW Document]. U. S. Dep. Labo. 2012 [cited;

436 Available from: https://www.osha.gov/video/respiratory protection/fittesting transcript.html (accessed

$437 \quad 4.10 .20)$.

438 21. Holshue ML, DeBolt C, Lindquist S, Lofy KH, Wiesman J, Bruce H, et al. First Case of 2019 Novel

439 Coronavirus in the United States. N Engl J Med. 2020 Jan 31.

440 22. van Doremalen N, Bushmaker T, Munster VJ. Stability of Middle East respiratory syndrome

441 coronavirus (MERS-CoV) under different environmental conditions. Euro Surveill. 2013 Sep 19;18(38).

442 23. Brownie C, Statt J, Bauman P, Buczynski G, Skjolaas K, Lee D, et al. Estimating viral titres in

443 solutions with low viral loads. Biologicals. $2011 \mathrm{Jul} ; 39(4): 224-30$.

444 24. Gelman A. Bayesian data analysis. Third edition. ed. Boca Raton: CRC Press; 2014.

445 25. Northrup JM, Gerber BD. A comment on priors for Bayesian occupancy models. PLoS One.

$446 \quad 2018 ; 13(2): \mathrm{e} 0192819$. 